\title{
Knowledge, Attitude, and Perception Toward Risk of HIV/AIDS: A Descriptive Study at Universitas Muhammadiyah Magelang
}

\author{
Prasojo Pribadi ${ }^{1 *}$, Rayi Citra Ayu Pangestuti ${ }^{1}$, Reni Mareta ${ }^{2}$, Sigit Priyanto $^{2}$ \\ ${ }^{1}$ Department of Pharmacy, Universitas Muhammadiyah Magelang, Magelang, Indonesia. \\ ${ }^{2}$ Department of Nursing Science, Universitas Muhammadiyah Magelang, Magelang, Indonesia. \\ *Corresponding author. Email: prasojopribadi@ummgl.ac.id
}

\begin{abstract}
Experiences or negative attitudes towards HIV, low knowledge and perception are also factor that can influence the emergence of stigma and discrimination. The primary objective of this study is to assessing the knowledge, attitude and perception among Faculty of Health Science students of Universitas Muhammadiyah Magelang towards risk of HIV/AIDS. Methods: The data was collected by questionnaire from students in five department Faculty of Health Science. Samples of 165 students using the proportional method. Each respondent's scores were totalled and individual average scale scores were analysed using descriptive analysis. Result: 53.34\% of Faculty of Health Sciences students have the level of knowledge towards risk of HIV and AIDS was moderate (range 51-74). 62.5\% of students have a positive attitude (0.63) and 51.5\% of students have a negative perception. There is significant correlation between knowledge and attitude. However, no significant correlation was found between knowledge and perception. Conclusions: Increase knowledge about HIV/AIDS through education and training since attending college, providing sufficient and up-to-date information about HIV/AIDS so as to be able to prepare health science faculty students to treat patients with HIV/AIDS and reduce negative stigma and discrimination.
\end{abstract}

Keywords: knowledge, attitude, perception, HIV/AIDS

\section{INTRODUCTION}

World Health Organization (WHO) stated that over the past few years shows that the group of adolescents and productive adults aged 15-24 years is one of the most vulnerable groups to HIV / AIDS [1]. Meanwhile, based on data from the KEMENKES RI in July-September 2012, there were 5.498 cases of recorded HIV cases, the highest percentage of HIV cases were reported in the 25 - 49 years age group $(73.7 \%)$, and followed by the $20-24$ years age group $(15.0 \%)$ and groups $>50$ years $(4.5 \%)$ with a ratio of men and women 1: 1, while AIDS cases from July to September 2012 the number of new AIDS cases reported was 1.317 cases [2].

HIV and AIDS are often associated with deviant behaviour such as homosexuals, sex workers, drug users or God's curse [3]. Therefore, the AIDS epidemic result in discrimination and prejudice against patients infected with HIV. Health workers increasingly fear the danger of being infected from this patient [4]. This has become one of the biggest obstacles in the prevention and control of Human Immunodeficiency Virus/Acquired Immune Deficiency Syndrome (HIV/AIDS) in Indonesia. The high stigma and discrimination against people with HIV/AIDS is reflected in cynicism, excessive feelings of fear, and negative experiences with HIV-positive patients. Many people think that HIV/AIDS-positive patients deserve to be punished for their own actions. They also assume that they are responsible for transmitting HIV/AIDS [5]. Stigma and discrimination against people infected with HIV /AIDS can increase social isolation and depression or barriers to access to health services for people with HIV/AIDS and have an impact on opening up the spread of AIDS, this is because the attitudes of health workers and people who are prejudiced can discouraging people from daring to do the test and will even make people feel unwilling to seek information and recovery efforts [3].

Many factors affect the occurrence of stigma in people living with HIV in society. In addition to experiences or negative attitudes towards HIV transmission, low knowledge is also a factor that can influence the emergence of stigma and discrimination [5]. The assessment of knowledge about HIV infection plays a major role in the prevention of the virus. This is important because knowledge can prevent a person from getting the infection of HIV. Most of the people with adequate knowledge will protect themselves better from getting a virus. Lack of knowledge can form a negative attitude towards people living with HIV [6]. People who have enough knowledge about risk factors, transmission, prevention, and treatment of HIV/AIDS tend not to be afraid and do not give stigma to people infected with HIV/AIDS [5]. Knowledge about HIV disease and how it is transmitted seems to be related to the willingness of health science faculty students and health workers to treat HIV patients. Therefore, knowledge about HIV/AIDS needs to be increased because it can cause an increase in the willingness and confidence of health science faculty students and health workers to treat HIV-positive 
patients [7]. Hence, it is important to gain insight about the level of knowledge and attitudes of health science faculty students and health workers towards HIV/AIDS-positive patients. The primary objective of this study is to assessing the knowledge, attitude and perception towards HIV/AIDS patients among students in the Faculty of Health Sciences, Universitas Muhammadiyah Magelang.

\section{METHODS}

\subsection{Study Design and Data Collection}

The research design is a descriptive study to find out the description of knowledge, attitude, and perception towards risk of HIV/AIDS among students of Faculty of Health Sciences, Universitas Muhammadiyah Magelang. The study was used cross-sectional survey was carried out from August 2019. Samples taken amounted to 165 students using the proportional method.

\subsection{Research Instrument}

Table 1 Demographic data of students

\begin{tabular}{|lrlr|}
\hline \multicolumn{1}{|c}{ Demographic Variables } & n (\%) & Demographic Variables & n (\%) \\
\hline Gender & & Year of students & $9(5.4)$ \\
Female & $151(91.5)$ & I & $44(26.7)$ \\
Male & $14(8.5)$ & II & $84(50.9)$ \\
& & III & $28(17)$ \\
& & IV & $41(24.8)$ \\
Age (In years) & Study Program & $65(39.4)$ \\
$19-22$ & & Associate degree of Pharm & $30(18.2)$ \\
$23-27$ & $134(81.2)$ & Bachelor degree of Pharm & $12(7.3)$ \\
$>27$ & $21(12.7)$ & Associate degree of Nurse & $17(10.3)$ \\
\hline
\end{tabular}

Most of the respondents are female, $91.5 \%(n=141)$ and the rest is male, $8.5 \%(n=14)$. In this study, a large proportion of the respondents' age is between 19-22 years old. The
The data collection was conducted by distributing the questionnaire. The research were used questionnaire adopted from Said [6]. The questionnaire was translated into Indonesian, and pilot tests were conducted on ten students outside the research subjects. Minor improvements were made after the pilot.

\subsection{Data Analysis}

Descriptive statistics were used to analyse the general description about the data including mean, median, frequency, standard deviation, and percentage. Significance value was set at $p<0.05$, and only significant results were discussed. Crosstab analysis was used to determine the relationship between demographic data and level of knowledge of HIV/AIDS. The Pearson's Correlation Coefficient is used to correlate demographic data towards knowledge, attitude, and perception towards HIV/AIDS infection and to determine the relationship between knowledge, attitude, and perception of HIV/AIDS infection.

Table 2 Knowledge of students regarding HIV/AIDS

\begin{tabular}{|lcc|}
\hline \multicolumn{1}{|c}{ Items } & $\begin{array}{c}\text { Correct Response } \\
\text { n (\%) }\end{array}$ & $\begin{array}{c}\text { Incorrect Response } \\
\text { n (\%) }\end{array}$ \\
\hline $\begin{array}{l}\text { People can get infected with HIV by using the same toilet seat with } \\
\text { someone who has HIV/AIDS }\end{array}$ & $120(72.7)$ & $45(27.3)$ \\
$\begin{array}{l}\text { People can get infected with HIV by injecting drugs with HIV by } \\
\text { injecting drugs with used needles }\end{array}$ & $164(99.4)$ & $1(0.6)$ \\
HIV can be transmitted from infected mother to child & $162(98.2)$ & $3(1.8)$ \\
People can get infected with HIV through social contacts & $144(87.3)$ & $21(12.7)$ \\
People can get infected with from mosquito spite & $103(62.4)$ & $62(37.6)$ \\
People can get infected with HIV being fed from the same plate with & $114(69.1)$ & $51(30.9)$ \\
a person living with HIV/AIDS & & \\
\hline
\end{tabular}

Based on Table 2, the items that use in assessing the knowledge of students regarding HIV/AIDS was shown. Data shows that most of the students know about the highest respondents are from the Bachelor degree of Pharm, $39.4 \%(n=65)$. Majority of the subjects are in year III, $50.9 \%(n=84)$. (Table 1$)$. transmission of HIV/AIDS. Hence, most of the students can answer the question correctly. However, there is a high number of students who uncertain whether HIV/AIDS can 
be transmitted through mosquito bite $62(37.6 \%)$ of the students answered this wrongly. Although, 51 (30.9\%) of numbers students also answered wrongly related to an item that HIV/AIDS transmission through being fed from the same plate with a person living with HIV/AIDS. However, for the item, people can get infected with HIV by using the same toilet seat with someone who has HIV/AIDS, 45 $(27.3 \%)$ of student's responses wrongly. Overall, respondents had a score of knowledge from 6 knowledgerelated questions.

Table 3 Student's level knowledge

\begin{tabular}{|lcc|}
\hline Level of Knowledge & n & \% \\
\hline Low Knowledge & 10 & 6.06 \\
Average & 88 & 53.34 \\
High Knowledge & 67 & 40.6 \\
Total & 165 & 100 \\
\hline
\end{tabular}

Accordingly, $40.6 \%$ were classified as having high knowledge. $53.34 \%$ shown average and $6.06 \%$ is low knowledge regarding HIV (Table 3). The sociodemographic characteristics are shown in Table 1. The proportion of the students' level of knowledge are depicted in Table 3. The result has shown that most of the students had a average knowledge of HIV/AIDS. However, no significant correlation between gender, age, study program, year of students towards knowledge $(P>0.05)$. This is similar to the findings of research by Petros et al. [8] which states that no significant statistical difference in knowledge about preventive measures was observed for the background characteristics of sex, religion and the college and the year in college the student belonged to Overall, the respondents in this study is Faculty of Health Science students. Health sciences students are most probably the health care worker who will typically have direct contact with HIV/AIDS patients as they will deliver health care services after completing their studies. Therefore, these results are obtained because most probably health science students have been given exposure to educational programs and clinical practices in their curriculum. This is consistent with research conducted by Waluyo [9] which states that there are no significant differences in the behaviour of male and female nurses towards PLHIV, nor is there a difference in the level of HIV/AIDS knowledge and the level of religiosity.

Table 4 Attitude towards HIV/AIDS

\begin{tabular}{|c|c|c|}
\hline Items & $\begin{array}{l}\text { Negative } \\
\text { n }(\%)\end{array}$ & $\begin{array}{c}\text { Positive } \\
\text { n }(\%)\end{array}$ \\
\hline $\begin{array}{l}\text { If one of your family members infected with HIV would you be } \\
\text { willing to care for him/her? }\end{array}$ & $12(7.3)$ & $153(92.7)$ \\
\hline $\begin{array}{l}\text { If you are infected with HIV would you prefer that this information } \\
\text { to remain a secret? }\end{array}$ & $115(69.7)$ & $50(30.3)$ \\
\hline $\begin{array}{l}\text { Would you be ready to eat from the same plate with a person you } \\
\text { know has HIV/AIDS? }\end{array}$ & $33(20)$ & $132(80)$ \\
\hline $\begin{array}{l}\text { If a student lives with HIV/AIDS should he/her be allowed to } \\
\text { continue to attend school/studies? }\end{array}$ & $24(14.5)$ & $141(85.5)$ \\
\hline $\begin{array}{l}\text { Would you accept to share the same class at school/college with } \\
\text { someone who you know is infected with HIV/AIDS? }\end{array}$ & $28(17)$ & $137(83)$ \\
\hline $\begin{array}{l}\text { If a professor is infected with HIV/AIDS should she/he be allowed } \\
\text { to continue to teach in the school/college? }\end{array}$ & $31(18.8)$ & $134(81.2)$ \\
\hline $\begin{array}{l}\text { If a health worker (doctor, nurse) is infected with HIV/AIDS should } \\
\text { she/ he be allowed to continue to work with patients? }\end{array}$ & $110(66.7)$ & $55(33.3)$ \\
\hline $\begin{array}{l}\text { If you know a food seller living with HIV/AIDS, would you buy } \\
\text { from him/her? }\end{array}$ & $135(81.8)$ & $30(18.2)$ \\
\hline Average scale score & 0.36 & 0.63 \\
\hline
\end{tabular}

Table 4 shows the score of attitude students on the HIV/AIDS. Most of the students showed positive attitudes towards willingness to take care of their family if they were infected with HIV/AIDS. Students also preferred to keep it secret if they were infected with HIV. Most of the students were positive to share the same class with someone with HIV, 137(83\%). They also agreed if a professor who is infected with HIV to be allowed to continue teaching, 134 $(81.2 \%)$. However, students showed a negative attitude reaction towards healthcare worker and food seller with HIV to continue working. They were also reluctant to buy from an HIV infected food seller 135(81.8\%).
Table 5 Student's level of attitude towards HIV/AIDS

\begin{tabular}{|c|c|c|}
\hline Level of Attitude & $\mathbf{n}$ & $\%$ \\
\hline Positive & 103 & 62.4 \\
\hline Negative & 62 & 37.6 \\
\hline Total & 165 & 100 \\
\hline
\end{tabular}

Table 5 shows the levels of attitude students on the HIV/AIDS, with $62.4 \%$ of students were classified as having a positive attitude towards HIV. A total of $37.6 \%$ were classified as having a negative attitude toward HIV/AIDS. There is a significant correlation between knowledge towards attitude, $(P=0,000)$. Emotional reactions also have an important role in health workers in the willingness to treat patients with HIV/AIDS.

In our study, the reason for the lack of certain knowledge may be because students are more oriented towards 
examinations and are not interested to extend their knowledge to the stigma and discrimination. This is consistent with research conducted by Abebe et al. [10] which states that they are not interest in increasing their knowledge to the stigma based on observations made around the place of care for HIV/AIDS patient. Inadequate knowledge may also be caused by deficiencies in the curriculum in presenting information about illness to students. Therefore, there needs to be an improvement in their curriculum, not only the medical aspects of HIV but also the social components, related with stigma and discrimination against HIV/AIDS patients. This is similar to the findings of research by Aggarwal [11] which states that in addition to lectures increasing the level of knowledge in education, there is a need to also bring about positive changes in the students' attitudes and behaviours towards patients with HIV/AIDS by making this portion of the curriculum more clinically oriented and removing misconceptions regarding transmission of the infection.

Table 6 Perception of students towards HIV/AIDS

\begin{tabular}{|lcc|}
\hline \multicolumn{1}{|c|}{ Items } & $\begin{array}{c}\text { Negative } \\
\text { n (\%) }\end{array}$ & \multicolumn{1}{|c|}{$\begin{array}{c}\text { Positive } \\
\text { n (\%) }\end{array}$} \\
\hline $\begin{array}{l}\text { Can people be infected with HIV from person who is seemingly } \\
\text { healthy? }\end{array}$ & $160(97)$ & $5(3)$ \\
Person living with HIV is a punishment for his/her behaviours? & $56(33.9)$ & $109(66.1)$ \\
HIV/AIDS & $100(60.6)$ & $65(39.4)$ \\
HIV/AIDS patient are normally sex workers? & $100(60.6)$ & $65(39.4)$ \\
\hline HIV/AIDS patients are dying very quickly? & $\mathbf{0 . 6 3}$ & $\mathbf{0 . 3 6}$ \\
\hline Average scale score
\end{tabular}

Table 6 shows, most of the students are a belief that HIV can be infected with people who are seemingly healthy 160 (97\%). A great number of students think that the HIV/AIDS patient is normally sex workers, $100(60.6 \%)$. Most of the students are certain whether HIV patients are dying very quickly. The four-items addressed perception toward HIV.

Table 7 Students level of perception towards HIV/AIDS

\begin{tabular}{|lcc|}
\hline \multicolumn{1}{|c}{ Level of Perception } & n & \% \\
\hline Positive & 80 & 48.5 \\
Negative & 85 & 51.5 \\
Total & 165 & 100 \\
\hline
\end{tabular}

Table 7 shows $48.5 \%$ of students were classified as having a positive perception towards HIV. A total of $51.5 \%$ were classified as having a negative perception toward HIV because they scored less than the mean. There is no correlation between knowledge and perception $(P=0.076)$. A lack of confidence of health worker in treating HIV/AIDS patients may be because they think negatively and were worried, assuming HIV patients can infect them. Overestimation of the transmission risk of HIV was the most essential reason for fear among Faculty of Health Science students in providing healthcare to HIV/AIDS patients. This study explain that the knowledge was not significantly associated with perception. These findings were in accordance with the studies done by Singh et al. [7].

\section{CONCLUSION}

The result of our study show that the faculty of health science students had moderate knowledge, with positive attitude. However, the perception of them is quite negative. There is significant correlation between knowledge and attitude. However, no significant correlation was found between knowledge and perception. Misunderstanding of the information that needs to be concerned. A health education program about HIV/AIDS should be held to help these students to understand better about the risk of HIV/AIDS and make them not to be afraid and do not give stigma to the patient who infected with HIV/ AIDS. Health students should also be aware of their own attitudes, because they have been shown to have an impact on the way they are working.

\section{ACKNOWLEDGMENT}

I gratefully thank to the principal of Faculty of Health Science Universitas Muhammadiyah Magelang for allowing me to conduct the research there.

\section{AUTHOR CONTRIBUTIONS}

Conceptualization (P.P, R.C.A.P); Material research preparation (P.P, R.C.A.P); Methodology (P.P); Data collecting (R.M, S.P, R.C.A.P); Data analysis and visualization (R.C.A.P); Writing - original draft (P.P, R.C.A.P); Presentation (R.C.A.P).

\section{REFERENCES}

[1] D. Sari, "Gambaran Pengetahuan, Sikap dan Perilaku Mengenai HIV/AIDS Pada Mahasiswa 
[7] V. P. Singh, O. I. Syazana, N. A. Rahmat, N. A.

Program Studi Pendidikan Dokter Universitas Tanjungpura," Universitas Tanjungpura, 2011.

[2] N. Andalia, Agnes, and M. Ridhwan, "Hubung an Antara Pengetahuan Dengan Persepsi Siswa Terhadap Penularan Penyakit AIDS," J. Serambi Ilmu, vol. 18, no. 1, pp. 51-58, 2017.

[3] A. Fitriani, Z. Shaluhiyah, and A. Suryoputro, "Stigmatisasi Bidan pada Ibu Hamil dengan HIV dan AIDS di Kota Semarang," J. Promosi Kesehat. Indones., vol. 8, no. 1, pp. 79-89, 2013.

[4] R. Li, W. Dong, W. He, and Y. Liu, "Chinese Dental Students' Knowledge and Attitudes toward HIV/AIDS," J. Dent. Sci., vol. 11, no. 1, pp. 72-78, 2016.

[5] Z. Shaluhiyah, S. B. Musthofa, and B. Widjanarko, "Public Stigma to People Living with HIV / AIDS," J. Kesehat. Masy. Nas., vol. 9, no. 4, pp. 333-339, 2014.

[6] N. Said, M. Ramadan, and A. Hamid, "University Students' Knowledge, Attitude, and Perception of Risk Related to HIV/AIDS," J. ASIAN Behav. Stud., vol. 3, no. 11, p. $34,2018$.
Abu Bakar, N. F. N. Abdul Razak, and S. Nettem, "Knowledge and Attitude of Dental Students towards HIV/AIDS Patients in Melaka," Malays J Med Sci, vol. 24, no. 3, pp. 73-82, 2017.

[8] B. Petros, S. Belayneh, and Y. Mekonnen, “AIDS and college students in Addis Ababa: A study of knowledge, attitude and behavior," Ethiop. Heal. Nutr. Res. Inst., no. 3, pp. 1-12.

[9] A. Waluyo, P. A. Nova, and C. Edison, "Perilaku Perawat Terhadap Orang Dengan HIV/AIDS di Rumah Sakit dan Puskesmas Agung," J. Keperawatan Indones., vol. 14, no. 2, pp. 127-132, 2011.

[10] N. Abebe et al., "AIDS \& Clinical HIV/AIDS Related Knowledge and Attitude among Health Science Student of Debre Markos University, North West Ethiopia, 2014," J AIDS Clin Res, vol. 6, no. 3, pp. 1-5, 2015.

[11] A. Aggarwal and S. R. Panat, "Knowledge, Attitude, and Behavior in Managing Patients with HIV/AIDS Among a Group of Indian Dental Students," J. Dent. Educ., vol. 77, no. 9, pp. 1209-1217, 2012. 